\title{
Organizational Climate And Its Influence On Organizational Commitment
}

\author{
Fauziah Noordin, Universiti Teknologi MARA, Malaysia \\ Safiah Omar, Universiti Teknologi MARA, Malaysia \\ Syakirarohan Sehan, Universiti Teknologi MARA, Malaysia \\ Shukriah Idrus, Universiti Teknologi MARA, Malaysia
}

\begin{abstract}
The findings of the study indicate that the employees perceived the organizational climate of their organization to be at a moderate level. The mean values for the components of the organizational climate ranged from the lowest of 3.38 to the highest of 3.77 of the 5-point Likert scale. Continuance commitment appears to be the lowest of the three components of the organizational commitment construct with a mean of 3.22. In terms of the correlations between the variables, the results indicate that continuance commitment has no correlations with organizational design, teamwork, and decision-making. All other variables show significant positive correlations. Overall, the findings of the present study indicate that there is a need to improve the current situation at ABC Company with respect to all the components of the organizational climate and organizational commitment.
\end{abstract}

Keywords: Organizational climate, affective commitment, continuance commitment, normative commitment

\section{INTRODUCTION}

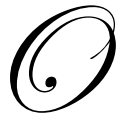

rganizational Climate Survey is the closest thing a business can get to a Profit and Loss statement of how well a company uses its people (Hay Group, 2009). The feedback of the survey will provide an organization with a really accurate picture of its current climate. This feedback will in turn help leaders understand the connection between their actions and the climate they create for their employees, understand the climate they themselves experience on a daily basis, can be used as part of an executive coaching intervention or any one-to-one coaching and developmental process, and can be employed as a Leadership Development tool either for individual leaders or across teams and work units (Hay Group, 2009).

Organizational climate affects organizational performance by influencing employee motivation. In most jobs, there is a gulf between what employees need do to 'get by' and what they can do if they perform at their fullest potential. A positive organizational climate is said to be the catalyst that will encourage this discretionary effort and commitment.

Many of organizational climate studies have been conducted across a range of industries in the western world. Yet no specific empirical study of organizational climate in the telecommunication industry, especially in Malaysia) has been undertaken to ascertain what effect this construct has on organizational commitment. Therefore, the research question addressed in this study is: What is the nature of influence that organizational climate has upon organizational commitment of employees within Malaysian telecommunicaton industry?

\section{ORGANIZATIONAL CLIMATE AND ORGANIZATIONAL COMMITMENT}

The climate of an organization refers to those aspects of the environment that are consciously perceived by organizational members (Armstrong, 2003). In short, it refers to how the members of an organization perceive it as it goes about its daily business. There is a general agreement that organizational climate is a multi-dimensional concept, and that a number of typical dimensions could be described. For the purpose of this study, the dimensions 
of organizational climate examined were organizational design, communication, leadership, teamwork, decisionmaking, culture, job satisfaction, and motivation. Organizational design refers to the process of constructing and adjusting an organization's structure to achieve its goals. Communication refers to the evoking of a shared or common meaning in another person. Leadership involve in influencing and directing people to achieve particular goals within the given time and place using the leaders capability and skills to make people working together. Teamwork is a process of working collaboratively with a group of people, in order to achieve a goal. Organizational culture is described as a pattern of basic assumption that are considered valid and that are taught to new members as the way to perceive, think, and feel in the organization. Job satisfaction is a self-reported positive emotional state resulting from the appraisal of one's job or from job experiences (Locke, 1976). Finally, motivation is referred to as an internal state or condition that activates behavior and gives direction and it develops desire or want that energizes and directs goal-oriented behavior.

Organizational commitment has been conceptualized by Meyer and Allen (1990) as having three dimensions, which they identified as affective, continuance and normative commitment. Affective commitment refers to the employee's emotional attachment to, identification with, and involvement in the organisation. Employees with a strong affective commitment continue employment with the organisation because they want to do so. Continuance commitment refers to an awareness of the costs associated with leaving the organisation. Employees whose primary link to the organisation is based on continuance commitment remain because they need to do so. Normative commitment reflects a feeling of obligation to continue employment. Employees with a high level of normative commitment feel that they ought to remain with the organisation.

Past research findings have indicated that there exist relationships between the dimensions of organizational climate and organizational commitment. For example, Spector (1997) cites that job satisfaction is a correlate and predictor of organizational commitment; Gregersen and Black (1996) posited that work process would enhance a sense of felt responsibility that led to an increase in commitment among employees; Varona (2002) found that there is a relationship between communication and organizational commitment in terms of feedback and responses from both upper level and employees; Mitchell et al (2001), Osbourn et al (1990), and Wellins, Byham, and Wilson (1991) indicate that teams contribute to better outcomes for business organization due to employees commitment to the organizations; and Angle and Perry (1981) posit that proper leadership and motivation influence commitment and would result in organizational effectiveness. In addition, Steel et al (1992) found that employee perception of decision-making influence was positively correlated with organizational commitment of employees. Finally, organizational commitment has been often cited in the literature to be both a dependent variable as well as variable for antecedents such as age, tenure, and education (Mathieu and Zajac, 1990; Mowday et al., 1979; Dunham et al., 1994; Fauziah 2008).

Based on the above discussion, the objectives of the present study are (1) To determine the level of the dimensions of organizational climate within a telecommunication company in Malaysia, (2) To determine the level of the dimensions of organizational commitment within a telecommunication company in Malaysia and (3) To determine the influence of organizational climate on organizational commitment of employees of a telecommunication company in Malaysia.

\section{RESEARCH METHODOLOGY}

\section{Respondents and Data Collection}

For this research, 150 employees from executive and non-executive level in ABC Company have volunteered to participate in the study. A pilot test was done prior to the main study. Analyses on the pilot test showed that the assessment instrument (questionnaire) is reliable and valid for the present study. Out of 150 questionnaires distributed to $\mathrm{ABC}$ Company, a total of 108 questionnaires from were completed and returned.

\section{Assessment Instrument}

The Organisational Climate Survey instrument in this study was developed based on an established assessment instrument on organizational climate which include Organizational Design, Communication, Leadership, 
Teamwork, Decision-Making, Culture, Job Satisfaction, and Motivation; and Organizational Commitment, instrument development by Allan and Mayer (1991).

The survey consisted of a series of 45 statements to which respondents were required to indicate based on a 5-point scale from strongly disagree to strongly agree and strongly dissatisfied to strongly satisfied. The responses to the survey were entered into a database and analyzed in a variety of ways using the Statistical Package for the Social Sciences (SPSS) analysis software.

\section{Results of the Study}

The respondents for ABC Company comprise 50\% female and 50\% male. Majority of the respondents are senior employees $(50.5 \%)$. Half of the total respondents are university graduates and have worked for more than 5 years in the organization (43.4\%) and 30\% have been holding the same position. In addition, $57.9 \%$ respondents received income less than RM2000 per month. The reliability test results and the means of the variables are shown in Table 1.

Table 1: Reliability Test Results

\begin{tabular}{|c|l|c|c|}
\hline No. & \multicolumn{1}{|c|}{ Organizational Climate: Components } & Cronbach's Alpha & Means \\
\hline 1. & Organizational Design & .883 & 3.67 \\
\hline 2. & Communication & .728 & 3.77 \\
\hline 3. & Leadership & .848 & 3.59 \\
\hline 4. & Teamwork & .828 & 3.55 \\
\hline 5. & Decision-Making & .750 & 3.69 \\
\hline 6. & Culture & .822 & 3.59 \\
\hline 7. & Job Satisfaction & .695 & .322 \\
\hline 8. & Motivation & & 3.62 \\
\hline Total mean for Organizational Climate is: 3.61 & & \\
\hline No. & \multicolumn{1}{|c|}{ Organizational Commitment: Components } & .741 \\
\hline 1. & Affective Commitment & .714 & \\
\hline 2. & Continuance Commitment & .717 & $\mathbf{3 . 3 9}$ \\
\hline 3. & Normative Commitment & & $\mathbf{3 . 2 2}$ \\
\hline Total mean for Organizational Commitment is: $\mathbf{3 . 3 6}$ & $\mathbf{3 . 4 6}$ \\
\hline
\end{tabular}

From Table 1 above, job satisfaction appears to have the lowest mean of 3.38 compared to the other components of organizational climate. Communication recorded the highest mean, i.e., 3.77. Overall, the total mean value for $\mathrm{ABC}$ Company organizational climate is 3.61 .

Table 2 shows the means for each individual statement on the assessment instrument.

Table 2: Individual Means - Organizational Design

\begin{tabular}{|c|l|c|c|}
\hline & \multicolumn{1}{|c|}{ Organization Design } & Mean & S. D \\
\hline 1. & The organization's goals are clear to me. & 3.71 & .700 \\
\hline 2. & The organization's objectives are clear to me. & 3.67 & .699 \\
\hline 3. & $\begin{array}{l}\text { Employees have a shared understanding of what the organization is } \\
\text { supposed to do. }\end{array}$ & 3.65 & .715 \\
\hline 4. & Roles and responsibilities within the group are understood. & 3.67 & .786 \\
\hline 5. & Clear reporting structures have been established. & 3.70 & .678 \\
\hline 6. & $\begin{array}{l}\text { Employees at this organization have the right skill sets to perform their } \\
\text { job functions. }\end{array}$ & 3.61 & .809 \\
\hline & Total Mean & $\mathbf{3 . 6 7}$ & \\
\hline
\end{tabular}


Employees in ABC Company are aware about the organizational design of the company. They have a moderately clear view on the objectives $($ mean $=3.71)$ and goals $($ mean $=3.67)$ and they know about their responsibilities towards the organization (mean $=3.67$ ). This is important as organization goals and objectives are a vital part that should be known and internalized by employees in order to perform, as well as having the right capabilities to perform their job functions. In addition, the employees moderately agree to a certain extent (mean $=$ 3.61) that they have the right skills to perform their job functions.

Table 3: Individual Means - Communication

\begin{tabular}{|c|l|c|c|}
\hline \multicolumn{1}{|c|}{ Communication } & Mean & S. D \\
\hline 1. & I receive the information I need to perform my job well. & 3.92 & .688 \\
\hline 2. & When I need help, I can ask others in my work group for suggestions or ideas & 3.85 & .845 \\
\hline 3. & Our face-to-face meetings are productive. & 3.54 & .785 \\
\hline & Total Mean & $\mathbf{3 . 7 7}$ & \\
\hline
\end{tabular}

Communication elements (Table 3) are at a moderate level. The mean scores range from 3.54 to 3.92. In ABC Company, the mean values for leadership measure are all above 3.5. This means that the employees moderately agree that the leadership (Table 4) in the company is a fair and acceptable level for them to perform their work routine.

Table 4: Individual Means - Leadership

\begin{tabular}{|c|l|c|c|}
\hline & \multicolumn{1}{|c|}{ Leadership } & Mean & S. D \\
\hline 1. & I am inspired by my manager. & 3.55 & .964 \\
\hline 2. & I clearly understand what my manager expects of me. & 3.69 & .851 \\
\hline 3. & My manager's actions are consistent with the company values. & 3.59 & .878 \\
\hline 4. & $\begin{array}{l}\text { My supervisor encourages people to speak up when they disagree with the } \\
\text { decisions. }\end{array}$ & 3.51 & .894 \\
\hline & Total Mean & $\mathbf{3 . 5 9}$ & \\
\hline
\end{tabular}

Table 5: Individual Mean - Teamwork

\begin{tabular}{|c|l|c|c|}
\hline & \multicolumn{1}{|c|}{ Teamwork } & Mean & S. D \\
\hline 1. & I feel my input is valued by my peers. & 3.63 & .746 \\
\hline 2. & I feel supported by other employees even in the face of challenging situations. & 3.65 & .778 \\
\hline 3. & People in other departments willingly share information with my department. & 3.35 & 1.029 \\
\hline 4. & Members of my work group vary widely in their skills and abilities. & 3.5 & .854 \\
\hline 5. & I have confidence and trust in my co-workers. & 3.64 & .769 \\
\hline & Total Mean & $\mathbf{3 . 5 5}$ & \\
\hline
\end{tabular}

Team work among the employees in ABC Company is at a moderate level. Nonetheless, the willingness to share information between employees from different departments appear to have a mean value that is lower than the other statements $($ mean $=3.35)$. This could perhaps be due to the fact that there are many departments in the company and competitions are high between them. Therefore, they prefer not to share information with each other.

Table 6 indicates a moderate level of employees' involvement in decision-making process. The employees perceived that the organization has not made much progress in providing equal opportunity for all employees to make decisions $($ mean $=3.52)$. 
Table 6: Individual Means - Decision-Making

\begin{tabular}{|c|l|c|c|}
\hline & \multicolumn{1}{|c|}{ Decision-Making } & Mean & S. D \\
\hline 1. & I feel free to tell people higher up what I really think. & 3.71 & 2.019 \\
\hline 2. & We seek multiple sources of information before making important decisions. & 3.80 & 2.296 \\
\hline 3. & I have the authority to do my job to the best of my abilities. & 3.83 & .841 \\
\hline 4. & $\begin{array}{l}\text { I feel that this organization is making good progress in providing equal } \\
\text { opportunity for all employees to make decision. }\end{array}$ & 3.52 & .819 \\
\hline 5. & I have the chance to use my new ideas in my task. & 3.59 & .856 \\
\hline & Total Mean & $\mathbf{3 . 6 9}$ & \\
\hline
\end{tabular}

Table 7 shows that employees in ABC Company felt that they are not valued enough by the organization (mean $=3.47$ ). The employees in ABC Company believe that they can, to a certain extent, balance the work and their personal life (mean $=3.65)$. In addition, they feel that the morale of the employees in the company $($ mean $=$ 3.64 and working environment $($ mean $=3.62)$ is at moderate level.

Table 7: Individual Means - Culture

\begin{tabular}{|c|l|c|c|}
\hline & \multicolumn{1}{|c|}{ Culture } & Mean & S. D \\
\hline 1. & This organization has a good working environment. & 3.62 & .987 \\
\hline 2. & I feel valued as an employee. & 3.47 & .965 \\
\hline 3. & Morale is high across the organization. & 3.64 & .862 \\
\hline 4. & Employees have a good balance between work and personal life. & 3.65 & .814 \\
\hline & Total Mean & $\mathbf{3 . 5 9}$ & \\
\hline
\end{tabular}

As shown in Table 8, the employees are only moderately satisfied with their salaries $($ mean $=3.15)$ At the same time, they experience stress at work (mean =3.34). Even though they are not satisfied with the changes for the salary increase they still like working in the organization (mean $=3.86$ ). This could be because there are no other jobs available to them at that point in time.

Table 8: Individual Means - Job Satisfaction

\begin{tabular}{|c|l|c|c|}
\hline & \multicolumn{1}{|c|}{ Job Satisfaction } & Mean & S. D \\
\hline 1. & In general, I like working here. & 3.86 & .863 \\
\hline 2. & The amount of work that I expected to do is reasonable. & 3.69 & .832 \\
\hline 3. & At work, I do not feel too much tension or stress. & 3.34 & 1.098 \\
\hline 4. & I feel satisfied with my changes for salary increases. & 3.15 & 1.145 \\
\hline & Total Mean & $\mathbf{3 . 3 8}$ & \\
\hline
\end{tabular}

Table 9: Individual Means - Motivation

\begin{tabular}{|c|l|c|c|}
\hline & \multicolumn{1}{|c|}{ Motivation } & Mean & S. D \\
\hline 1. & I am energetic and enthusiastic about my work. & 3.75 & .728 \\
\hline 2. & This organization challenges me to strive for ambitious goals. & 3.77 & .721 \\
\hline 3. & I receive a great deal of encouragement and recognition. & 3.46 & .830 \\
\hline 4. & I was appropriately rewarded for my performance. & 3.50 & .985 \\
\hline & Total Mean & $\mathbf{3 . 6 2}$ & \\
\hline
\end{tabular}

Table 9 shows that the level of motivation in ABC Company is at a moderate level (mean = 3.62). Overall, the employees are moderately enthusiastic about their job (mean $=3.75)$, strive for ambitious goal $($ mean $=3.77)$, and feel that they are moderately rewarded for their performance (mean $=3.50$ ). In addition, the employees do not feel that they receive a great deal of encouragement and recognition $($ mean $=3.46)$. 
Table 10: Individual Means - Affective Commitment

\begin{tabular}{|l|l|c|c|}
\hline & \multicolumn{1}{|c|}{ Affective Commitment } & Mean & S. D \\
\hline 1. & I would be very happy to spend the rest of my career in this organization. & 3.42 & 1.049 \\
\hline 2. & I enjoy discussing about my organization with people outside. & 3.49 & 1.013 \\
\hline 3. & I really feel as if this organization's problems are my own. & 3.34 & .951 \\
\hline & Total Mean & $\mathbf{3 . 3 9}$ & \\
\hline
\end{tabular}

Employees in $\mathrm{ABC}$ Group appear to have a moderate level of affective commitment with mean values ranging from 3.34 to 3.49. This indicates that employees do not have a high emotional attachment to $\mathrm{ABC}$ Company, in other words, they work there not because they really want to.

Table 11: Individual Means - Continuance Commitment

\begin{tabular}{|l|l|c|c|}
\hline & \multicolumn{1}{|c|}{ Continuance Commitment } & Mean & S. D \\
\hline $1 .^{*}$ & It would be very hard for me to leave my job right now even if I wanted to. & 3.55 & .993 \\
\hline 2. & $\begin{array}{l}\text { Too much of my life would be disrupted if I decided to leave my job at this } \\
\text { organization right now. }\end{array}$ & 3.49 & .894 \\
\hline $3 .^{*}$ & It wouldn't be too costly for me to leave my job at this company in the near future. & 2.71 & .824 \\
\hline 4. & $\begin{array}{l}\text { Right now, staying with my job at this organization is a matter of necessity as } \\
\text { much as desire. }\end{array}$ & 3.55 & .815 \\
\hline & Total Mean & $\mathbf{3 . 2 2}$ & \\
\hline
\end{tabular}

** Reverse-worded statements

Table 11 shows that the statements in the continuance commitment measure have mean values from the lowest of 2.71 to the highest of 3.55. It seems that the employees in ABC Company would not hesitate to leave the company in the future and this is not a good indicator for the company.

Table 12: Individual Means - Normative Commitment

\begin{tabular}{|c|l|c|c|}
\hline & \multicolumn{1}{|c|}{ Normative Commitment } & Mean & S. D \\
\hline 1. & $\begin{array}{l}\text { Things are better when people stayed with one organization for most of their } \\
\text { career. }\end{array}$ & 3.45 & 1.002 \\
\hline 2. & I was taught to believe in the value of remaining loyal to one organization. & 3.32 & 1.009 \\
\hline 3. & I think that people these days move from one company to another too often. & 3.84 & .841 \\
\hline & Total Mean & $\mathbf{3 . 4 6}$ & \\
\hline
\end{tabular}

As indicated in Table 12, the mean values for the statements in the normative commitment measure range from 3.32 to 3.84. The employees perceived job hopping do take place, but not rampantly, and that people do not really believe in being loyal to just one organization.

In terms of the correlations between the variables, the results as shown in Table 13 indicate that continuance commitment has no correlations with organizational design, teamwork, and decision-making. In addition, normative commitment has no correlation with decision-making component of the organizational climate. All other variables show significant positive correlations between them.

Table 13: Correlation between Employees' Organizational Climate and Organizational Commitment

\begin{tabular}{|c|c|c|c|}
\hline \multirow{2}{*}{$\begin{array}{c}\text { Dimensions of } \\
\text { Organizational Climate }\end{array}$} & Affective & Continuance & Normative \\
\cline { 2 - 4 } & $.536^{* *}$ & .167 & $.452^{* *}$ \\
\hline Organizational design & $.488^{* *}$ & $.301^{*}$ & $.271^{* *}$ \\
\hline Communication & $.380^{* *}$ & $.376^{* *}$ & $.310^{* *}$ \\
\hline Leadership & $.469^{* *}$ & .07 & $.267^{* *}$ \\
\hline Teamwork & $.264^{* *}$ & .059 & .187 \\
\hline Decision-making & $.636^{* *}$ & $.326^{* *}$ & $.482^{* *}$ \\
\hline Culture & $.596^{* *}$ & $.586^{* *}$ & $.429^{* *}$ \\
\hline Job satisfaction & $.597^{* *}$ & $.491^{* *}$ & $.594^{* *}$ \\
\hline Motivation & & & \\
\hline
\end{tabular}

* Significant at 0.05 level (2-tailed) $\quad * *$ Significant at 0.01 level (2-tailed) 


\section{CONCLUSION AND IMPLICATION TO MANAGEMENT}

The study reveals that five of the dimensions of organizational climate, which are job satisfaction, motivation, culture, leadership, and teamwork, are critical since they have the lowest mean values compared to communication, decision-making, and organizational design. In addition, all the components of organizational commitment appear to have low mean values.

The main issue in ABC Company is that the employees are ready to job hop if and when they have better job offers in the future. To mitigate this risk, management should develop strategies to retain employees in order to avoid high labor turnover in the future. Another issue that arises from the employees is the fact that salaries are not up to their expectations. Phillips (1990) suggests that of the cost of employee turnover averages approximately 1.5 times the annual salary of the worker being replaced. This estimate includes not only direct recruiting costs associated with filling a position, but the lost productivity in the workplace as departing employees prepare to leave and then as positions are left vacant until a replacement is found.

The overall level of organizational climate for ABC Company is at best moderate. There is no variable that had a mean value of equal or more than 4.0. The critical issue that ABC Company faces is that the employees are not satisfied with their salaries and they also felt that they have not been appropriately rewarded for their performances. The company should re-evaluate the salaries package to make sure that they meet the market rate. The rewards package or known as the 'fringe benefits' also has to be evaluated to make it more attractive. A study by Rose \& Ahrens (1996) found that 82 percent of the managers believed that work/life benefits will become increasingly important to ensure productivity and reduce absenteeism and stress. Clearly, many employers not only expect family-supportive fringe benefits to provide personal value to workers, but to improve productivity and profitability.

Most of the respondents in $\mathrm{ABC}$ Company suggested that the companies should evaluate the employee's salaries since the pay for these employees are low where most of them are receiving lower than RM 2000 per month. Pay alone may or may not be the only issue that determines the feelings of dissatisfaction of the employees. There are other things besides pay that are needed to attract, retain, and motivate employees. According to McAdams (1996), the reward plan is a way to energize the people and hone their skills and attention so that they are operating at close to peak performance. One type of the reward plan is called cafeteria compensation. The cafeteria compensation promotes a compensation policy that allows employees to do some configuring of their compensation package. For an organization to consider this solution, it needs to understand five key components of cafeteria compensation criteria:

(1) A clear understanding of what organization pay employees for;

(2) An understanding of what accomplishment organization want from employees;

(3) An understanding that employee compensation consists of both investments and rewards;

(4) An understanding of the need to articulate the compensation philosophy in a compensation policy; and

(5) A compensation distribution matrix.

Other than tangible benefits, the compensation can also be in terms of intangible or known as the softer side of compensation. The researcher finds that to retain the employees, organization must also compensate them with intangible benefits, such as:

(1) Meaningful work - Employees have challenging and significant work;

(2) Business Information - Employees have a solid understanding of the business and ongoing access to relevant information;

(3) Leadership- Top leadership is fully committed;

(4) Employee involvement - Employees make meaningful decisions or have an input into significant decisions;

(5) Performance feedback - Employees get ongoing feedback from multiple sources on their contribution to the business;

(6) Career management - The company makes a long-term commitment to employee career growth. 
One of critical issues that should be of the main concern of ABC Company is the fact that the majority of the respondents who answered the open-ended questions have emphasized their dissatisfaction in terms of the high level of cronyism. This issue should be of concern to the company as this may affect the morale of the employees. In order to deal with this situation ABC Company needs to consider organizing or conducting values and ethics training programs to ensure that its employees understand the real value(s) and work ethics espoused by the company.

The correlations between majority of dimensions of organizational climate and organizational commitment show that organizational climates are significantly and positively related in a Malaysian telecommunication environment. Knowing that this type of relationship exist between organizational climate and organizational commitment may allow management to find ways to potentially reduce absenteeism, turnover, and minimize other negative aspects of the workplace. Management then can look at both organizational climate and organizational commitment variables to identify targets for improvement.

The findings of this study have a few implications for human resource management (HRM). First, the climate of an organization affects both the employees' physical exertion of their bodies and the mental exertion of their minds. Guzley (1992) discover that a willingness to exert considerable effort on behalf of the organization is one aspect of organizational commitment. Effort tended to be related to those employees who had a sense of control over their job situations and are committed to the organization (McMurray, Scott, and Pace, 2004). Furthermore, a positive organizational climate encourages commitment to the organization. Thus HRM practitioners should do all they possibly can to help create positive employee perceptions since those positive perceptions are the heart of the organization's climate and employee commitment. Second, it is particularly important for HRM practitioners to be aware of ways to measure the climate generated by employee perception. They must gain information from the organizational climate survey from the employees' perspectives and pay particular attention at what employees consider to be the main constraints to developing positive perceptions of aspects of the organization. Finally, HRM practitioners should get support from the top management and be prepared to get them to act on the information obtained from the organizational climate survey. Hence, the HRM practitioners should prepare a plan of action to deal with the negative perceptions that could lead to an unhealthy climate.

In conclusion, it is hoped that this research would provide guidance to $\mathrm{ABC}$ Company to improve its employees' level of performance, productivity, efficiency and to create an environment in the organization as the most attractive and conducive place to work. This study should be seen as a key step in the formulation of a transformation action guide for the ABC Company to indicate problematic areas in working life at the company. It is anticipated that this study will serve as a "baseline measure" of the organizational climate at the ABC Company, partly to describe the climate at present, but also to identify aspects that can be changed. In other words, it is an indication of the company's decision to follow evidence-based planning and intervention in its transformation action plan. If the study is to be repeated some years later, it will enable a comparison between these "baseline measures" and subsequent changes. It is hoped that the findings of this study will aid $\mathrm{ABC}$ Company to improve the organizational climate and to increase the commitment of their employees.

\section{AUTHOR INFORMATION}

Fauziah Noordin is a professor of Human Resource Management at the Faculty of Business, Universiti Teknologi MARA, Malaysia.

Safia Omar is a post-graduate student of Faculty of Business Management, Universiti Teknologi MARA, Malaysia.

Syakirahrohan Mohd Sehan is a post-graduate student of Faculty of Business Management, Universiti Teknologi MARA, Malaysia.

Syukurriah Idrus is a post-graduate student of Faculty of Business Management, Universiti Teknologi MARA, Malaysia. 


\section{REFERENCES}

1. Allen, N.J., \& Meyer, J.P. (1990). The measurement and antecedents of affective, continuance, and normative commitment to the organisation. Journal of Occupational Psychology, 63, 1-18.

2. Angel, H.L. and Perry, J.L. (1981). Empirical assessment of organizational commitment and organizational effectiveness. Administrative Science Quarterly, Vol. 15 No. 4, pp. 1-14.

3. Angle, H., Perry, J. (1981). An empirical assessment of organizational commitment and organizational effectiveness. Administrative Science Quarterly, Vol. 26 No.1, pp.1-14.

4. Armstrong, A. (2003). Corporate governance: Can governance standard change corporate behavior? Australian Journal of Professional and Applied Ethics, 5(2) pp 1-10.

5. Burke, W. W. (2002 and 1994). Readings from Organization Change: Theory and Practice. Thousand Oaks: Sage Publications and (1994) Organization Development; Reading: Addison-Wesley Publishing Company.

6. Dunham, R. B., J. A. Grube and M. B. Castaneda. (1994). Organizational commitment: The utility of an integrative definition. Journal of Applied Psychology 79: 370-380.

7. Fauziah Noordin, Rahmah Mohd Rashid, Rohani Ghani, Rasimah Aripin, and Zabani Darus. (2008). Teacher professionalization and organizational commitment. Presented at the EABR, Germany.

8. Gregersen, H.B. and Black, J.S. (1996) 'Multiple commitments upon repatriation: The Japanese experience', Journal of Management, 22(2): 209-229.

9. HayGroup. (2009). Australia: HayGroup. www.haygroup.com.au

10. Locke, E. A. (1976). The nature and causes of job satisfaction. In M. D. Dunnette (Ed.), Handbook of Industrial and Organizational Psychology (pp. 1297-1349). Chicago, IL: Rand McNally.

11. Mathieu, J.E., Zajac, D. (1990), A review and meta-analysis of the antecedents, correlates, and consequences of organizational commitment. Psychological Bulletin, Vol. 108 pp.171-94.

12. McAdams,. J. (1996). The reward plan advantage. Jossey-Bass Publishers. USA

13. Mitchell, T.R., Holtom, B.C., Lee, T.W., Sablynski, C.J. \& Erez, M. (2001). Why people stay: Using job embeddedness to predict voluntary turnover. Academy of Management Journal, 44. 1102-1121.

14. Meyer, J.P. and Allen, N, J. (1991). A three component conceptualization of organizational commitment. Human Resource Management Review, Vol. 1: 61-89.

15. Mowday, R.T, Steers, R.M, Porter, L.W (1979). The measurement of organizational commitment. Journal of Vocational Behavior, Vol. 14 pp.224-47.

16. Orsburn, J.D., Moran, L., Musselwhite, E. \& Zenger, J.H. (1990). Self-directed work teams:The new American challenge. Illinois: Business One Irwin.

17. Phillips, J.D. (1990). The price tag on turnover. Personnel Journal, No.December, .

18. Rose, K., Ahrens, A. (1996). The changing nature of work/life benefits: Owens Corning's experience. Benefits Quarterly, Vol. 12 No.4, pp.8-11.

19. Spector, P.E. (199)7. Job Satisfaction: Applications, Assessment, Cause and Consequences. Sage.

20. Varona F. (2002. Conceptualization and management of communication satisfaction and organizational commitment in three Guatemalan organizations. American Communication Journal. Volume 5, Issue 3.

21. Wellins, R.S., Byham, W.C. \& Wilson, J.M. (1991). Empowered teams: creating self-directed workgroups that improve quality, productivity and participation. San Francisco: Jossey-Bass. 
NOTES 